Bioeksperimen

Volume 2 No. 1, (Maret 2016)

ISSN 2460-1365

\title{
SINYAL INTRASEL PEMICU REORGANISASI SITOSKELETON SEL MAST PADA REAKSI HIPERSENSITIVITAS TIPE I
}

\author{
Safari Wahyu Jatmiko \\ Departemen Patologi Klinik \\ Fakultas Kedokteran Universitas Muhammadiyah Surakarta \\ E-mail korespondensi: safari.wahyu@ums.ac.id
}

\begin{abstract}
Mast cells plays an important role in the occurrence of type I hypersensitivity reaction. Degranulation is believed to underlie the role of mast cells in eliciting the reaction. The process of mast cell degranulation occurs due to migration of mast cell granules from cytoplasm to the cell membrane and release granule contents into the environment. It is determined by the reorganization of the cytoskeleton composed of microtubules, actin microfilaments, and intermediate filaments. Cytoskeleton reorganization begins with mast cell activation by binding between the allergens with $I g E$ attached to FceR. Mmast cells activation is reinforced by ties between $c$-Kit on the membrane surface of mast cells with c-Kit ligand. This raises a series of activation of intracellular processes that trigger the initiation of reorganization.
\end{abstract}

Keywords: mast cell, intracellular signal,cytoskeleton, type I hipersensitivitas

\begin{abstract}
Abstrak - Sel mast mempunyai peranan yang penting dalam terjadinya reaksi hipersensitivitas tipe I. Degranulasi sel mast diyakini mendasari peran sel mast dalam memunculkan reaksi tersebut. Proses degranulasi sel mast terjadi karena berpindahnya granula sel mast dari sitoplasma menuju ke membran sel dan memuntahkan isi granula ke lingkungan sekitarnya. Proses transport ini sangat ditentukan oleh reorganisasi sitoskeleton yang terdiri atas mikrotubulus, aktin mikrofilamen, dan intermediate filament. Reorganisasi sitoskeleton diawali dengan aktifasi sel mast oleh ikatan antara alergen dengan IgE yang menempel pada FceR. Aktfasi sel mast diperkuat dengan adanya ikatan antara c-Kit pada permukaan membran sel mast dengan c-Kit ligan. Aktifasi ini menimbulkan serangkaian proses intrasel yang memicu inisiasi reorganisasi.
\end{abstract}

Kata kunci: sel mast, sinyal intrasel, sitoskeleton, Hipersensitivitas tipe I

\section{PENDAHULUAN}

Sel mast pertama kali dideskripsikan oleh Friedrich von Recklinghausen pada tahun 1863. Pada tahun 1878 Paul Ehrlich mendeskripsikan hal yang sama dan memberi nama matzellen yang berarti sel yang kenyang makanan (Blank et al, 2013). Belakangan diketahui bahwa matzellen berperan dalam munculnya alergi, imunitas terhadap parasit, inflamasi, dan homeostasis. Saat ini matzellen lebih dikenal dengan nama sel mast (Beaven, 2009).

Sel mast bisa berbentuk bulat, oval ataupun gelondong dengan ukuran 7-20 $\mu \mathrm{m}$. Secara mikroskopis tampak tonjolantonjolan sitoplasma yang disebut dengan microplicae. Granula sel mast terwarna dengan methilen blue dan akan terlihat 
metakromasi. Membran sel mast dilengkapi dengan berbagai reseptor seperti FceR, $\mathrm{Fc} \gamma \mathrm{R}, \mathrm{CR}$ (complemenr receptor), reseptor $\beta 2$ adrenergik, reseptor Adenosin, reseptor TSLP (Thymic Stromal Lymphopoietin) dan IL-33R (Interleukin 33 receptor) (Jatmiko \& Aisyah, 2015).

Telah diyakini bahwa sel mast banyak ditemukan di jaringan ikat dan berperan penting dalam munculnya reaksi hipersensitivitas tipe I. Keterlibatan sel mast dalam reaksi hipersensitivitas tipe I di perankan oleh berbagai senyawa yang tersimpan di dalam granula (Amin, 2012; Braddinget al, 2006).

\section{INISIASI DEGRANULASI SEL MAST}

Pada pasien dengan reaksi hipersensitivitas tipe I, sel mast telah tersensitisasi oleh alergen. Sel mast pada kondisi ini mengandung 500.000 molekul IgE pada permukaan membran selnya. Bagian Fab dari IgE dalam posisi bebas sedangkan bagian Fc berikatan dengan
FceRI. Alergen yang masuk akan ditangkap oleh bagian Fab dari IgE. Ikatan silang antara alergen dengan minimal 2 molekul IgE akan mengaktifkan sel mast. Ikatan ini merupakan faktor yang mengawali terjadinya degranulasi (Amin, 2012).

Aktifasi sel mast oleh alergen diketahui ditingkatkan oleh adanya Stem Cell Factor(SCF) yang sering disebut juga sebagai c-Kit ligan. Saat ini diketahui bahwa SCF dihasilkan oleh sel endotel dan sel fibroblast (Lennartsson \&Rönnstrand, 2012; Theoharideset al, 2010).

\section{SINYAL INTRASEL PEMICU} REORGANISASI SITOSKELETON

Ikatan antara alergen dengan IgE dan c-Kit ligan dengan c-Kit memicu serangkaian proses sinyal intrasel yang memicu degranulasi. Proses perjalanan sinyal intrasel yang memicu reorganisasi sitoskeleton dapat dilihat dalam gambar 1 di bawah ini.

\section{$\operatorname{IgE}+$ allergen}

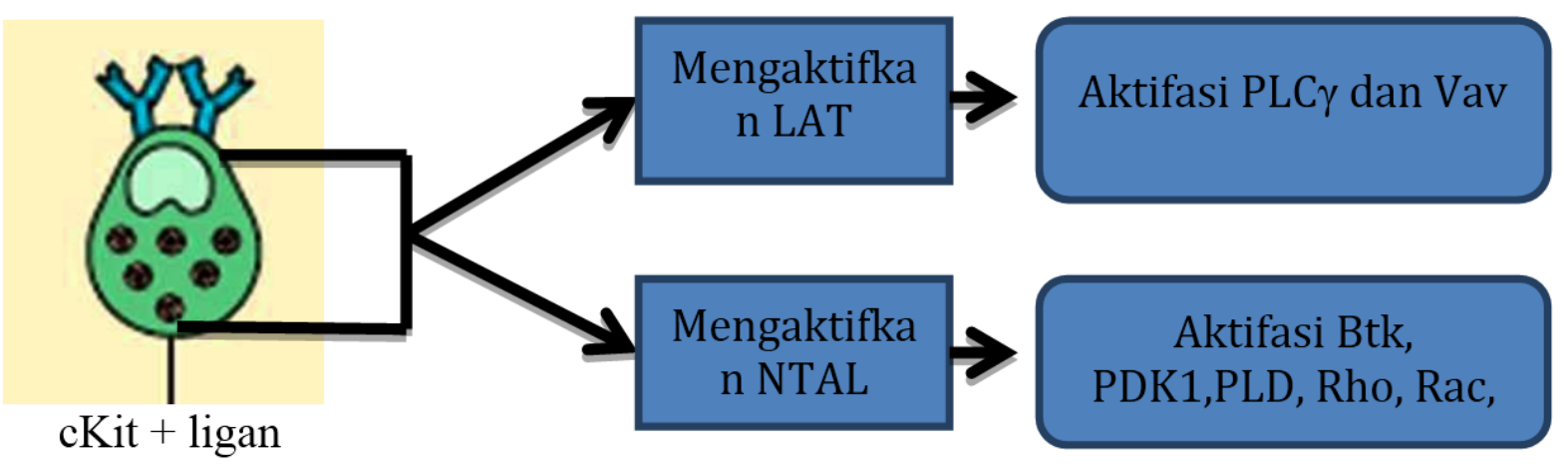

Gambar 1. Skema aktifasi sel mast (keterangan lihat teks) 


\section{AKTIFASI SEL MAST OLEH IgE}

Ikatan silang alergen dengan minimal dua FceRI $\alpha$ mengaktifkan protein Fyn dan Lyn (Pullenet al, 2012). Aktifasi Fyn dan Lyn memfosforilasi motif ITAM (Immunoreceptor Tyrosine Activation Motif) dari FceRI $\beta$ dan FceRI $\gamma$. Fosforilasi ini membuat protein Syk menempel kepada ITAM. Penempelan Syk menimbulkan perubahan konformasional dari Syk itu sendiri dan menyebabkan meningkatnya kemampuan aktifitas enzimatik dari Syk (Siraganianet al, 2010).

Selain memicu fosforilasi ITAM, Fyn yang aktif juga mengaktifkan protein Syk dan Gab2 (Grb-2 Associated binding protein 2) sedangkan Lyn mengaktifkan Syk (Okayama et al, 2012; Raet al, 2012; Sibilano et al, 2014). Selanjutnya Syk memicu fosforilasi NTAL (Non T Cell Activation Linker), LAT (Linker for Activation of $T$ Cells), dan mendorong terjadinya reorganisasi sitoskeleton (Polakovicova et al, 2014; Draber et al, 2012; Tumova'et al, 2010).

\section{Efek Fosforilasi NTAL}

NTAL yang telah terfosforilasi menarik Grb2 (Orr\& McVicar, 2011; Yamasakiet al, 2007). Melekatnya Grb2 kepada NTAL menjadikan Gab2 yang telah diaktifkan oleh Fyn bergabung dengan NTAL. Setelah Gab2 membentuk kompleks dengan Grb2, maka PI3K (Phosphatidylinositol 3 Kinase) ikut begabung dengan kompleks tersebut (Siraganian, 2003; Yu et al, 2006). Kompleks signalosom yang terbentuk kemudian mengaktifkan berbagai protein lain yang penting untuk proses degranulasi.

\section{Aktifasi Btk (Bruton Tyrosine Kinase)}

PI3K yang membentuk kompleks signalosom mengubah Phosphatidylinositol $(4,5)$ biphosphate yang terdapat pada lipid raft menjadi Phosphatidylinositol $(3,4,5)$ triphosphate. Perubahan tersebut menarik Btk menuju ke membran sel. Pertemuan Phosphatidylinositol $(3,4,5)$ triphosphatedengan Btk membuat Btk menjadi aktif. Btk kemudian mengaktifkan PLC $\gamma$ (Phospholipase $\mathrm{C} \gamma$ ) yang akan memecah Phosphatidylinositol $(4,5)$ biphosphate menjadi IP3 (inositol triphosphate) dan DAG (Diacyl Glyserol). Kedua zat ini mempunyai fungsi yang berbeda. DAG mengaktifkan PKC (Protein Kinase C) sedangkan IP3 memicu peningkatan kadar kalsium intrasel (Draber et al, 2012).

a. Peran IP3

Peningkatan kalsium intrasel diawali dengan ikatan antara IP3 dengan reseptor IP3 pada membran retikulum endoplasma. Hal ini memicu keluarnya ion kalsium ke dalam sitoplasma. Retikulum endoplasma yang kekurangan ion kalsium merangsang sensor kalsium STIM (Stromal Interaction Molecule) pada retikulum endoplasma. STIM kemudian bergerak ke arah membran plasma untuk berikatan dengan kanal kalsium yang terdiri atas Orai dan TRPC (Transient Receptor Potential Canonical). Ikatan antara STIM dengan Orai dan TRPC distabilkan oleh CRACR (Calsium Release-activated Calsium Current Regulator). Akibat dari ikatan ini adalah terbukanya kanal kalsium sehingga kalsium masuk ke dalam sel (Ha'jkova'et al, 2011; Shen, Frieden, Demaurex., 2011).

Peningkatan ion kalsium di dalam sel mast menyebabkan terjadinya depolimerisasi F-aktin. Depolimerasisasi ini diperantarai oleh berbagai protein lain yang menjadi 
aktif dengan meningkatnya ion kalsium (Draber et al, 2012).

b. Peran PKC

Sel mast mengandung PKC konvensional (PKC $\alpha$ dan PKC $\beta$ ), PKC novel (PKC $\theta$ ), dan PKC atipik (PKCל dan $P K C \lambda$ ). Ion kalsium dan DAG mengaktifkan PKC konvensional sedangkanDAGsendiritanpabantuan ion kalsium mengaktifkan PKC novel. PKC yang aktif akan mempengaruhi degranulasi sel mast dengan cara (1) memfosforilasi MARCK (myristoylated alanine-rich protein kinase $C$ substrate) yang memaksa MARCK terlepas dari Phosphatidylinositol $(4,5)$ biphosphate. Hal ini menyebabkan bergabungnya synaptogagmindengan membran plasma sehingga terjadilah degranulasi. (2) PKC mengaktifkan ADAP yang akan mempengaruhi MTOC. (3) PKC mempengaruhi Ras untuk aktif sehingga terjadilah reorganisasi mikrotubulus (Gadi et al, 2011; Huse, 2012; Lessmannet al, 2006; Liu et al, 2001).

\section{Aktifasi PDK1 (Phosphoinositide Dependent Kinase 1)}

Phosphatidylinositol $(3,4,5)$ triphosphate yang terbentuk akibat aktifnya PI3K menarik PDK1 ke membran sel. Kemudian PDK1 bergabung dengan Akt yang akan diikuti dengan aktifnya Akt. Akt yang telah aktif kemudian memfosforilasi GSK3 $\beta$ (Glycogen Synthase Kinase $3 \beta$ ) dengan bantuan DOCK5. Penghambatan GSK3 $\beta$ memicu terjadinya pembentukan mikrotubulus sehingga terjadi degranulasi sel mast (Kim, Radinger, Gilfillan., 2008; Ogawa et al, 2014).

\section{Aktifasi PLD (Phospholipase D)}

Protein lain yang diaktifkan oleh PI3K adalah PLD yang kemudian mengaktifkan sphingokinase. Fungsi sphingokinase adalah mengubah sphingosine menjadi sphingosine-1 phosphate. Hasil akhir dari proses ini adalah semakin meningkatnya kadar ion kalsium di dalam sel sehingga memicu depolimerisasi F-aktin (Rivera \& Gilfillan, 2006).

\section{Aktifasi Rho}

Adapter protein Gab2 dan PI3K yang tergabung di dalam signalosom mengaktifkan Rho. Phosphatidylinositol $(3,4,5)$ triphosphate juga mengaktifkan Rho dengan cara menarik GEF (GTP Exachange Factor) sehingga terjadi pertukaran GDP dengan GTP pada Rho (draber et al, 2012; Nishidaet al, 2005). Protein Rho selanjutnya mempengaruhi mDia (Mammalian diaphanous protein) dan Rho Kinase. Fungsi dari pengaktifan mDia adalah untuk menstabilkan microtubules plus ends sedangkan Rho Kinase mempengaruhi vimentin (Schwartz, 2003).

\section{Aktifasi Rac}

Phosphatidylinositol triphosphate, PI3K, dan Btkmengaktifkan Rac dengan proses yang mirip dengan pengaktifan Rho. Target dari Rac adalah PAK ( 21 Activated Kinase), OP18 (oncoprotein18), dan IQGAP (IQ motif containing GTPase activating protein). Penghambatan OP18 dan pengaktifan PAK merangsang pemanjangan mikrotubulus, sedangkan IQGAP akan membentuk kompleks dengan CLIP170 dan microtubule plus end untuk mengatur 
polaritas mikrotubulus (Allen et al, 2009; Nayaket al, 2013).

\section{Aktifasi cdc42}

Phosphatidylinositol

triphosphate sebagai hasil penambahan phosphatepadaphosphatidylinositol $(4,5)$ biphosphate oleh PI3K berperan penting dalam aktifasi cdc42. Saat ini diketahui bahwa cdc42 menjadikan PAK1 dan GSK-3ßsebagai target downstream. Fungsi utama keduanya adalah reorganisasi mikrotubulus (Draber et al, 2012; Melendez, Grogg, Zheng., 2011).

\section{Aktifasi LAT}

LAT yang terfosforilasi ketika sel mast aktif menarik protein GADs (Grb2related adapter protein). GADs berfungsi untuk menjembatani SLP76 (SH2domain-containing leukocyte protein of 76 $k D a)$ agar membentuk kompleks dengan LAT. Slanjutnya SLP76 menarik PLC $\gamma$ dan Vav. LAT juga diketahui membentuk kompleks dengan Grb2-Sos-Vav (Draber et al, 2012; Huse, 2009).

Pengaruh aktifasi PLC $\gamma$ sama seperti aktifasi PLC $\gamma$ oleh NTAL. Pembahasan sinyal downstream PLC $\gamma$ telah disampaikan pada sub bab sebelumnya.

Vav diketahui mempunyai peran dalam degranulasi sel mast karena kemampuannya dalam mengaktifkan Ras, Rac, dan Cdc42. Ketiganya merupakan pemicu reorganisasi mikrotubulus (Draber et al, 2012).

\section{AKTIFASI MELALUI C-KIT}

c-Kit atau CSF reseptor akan mengenali c-Kit ligan dan membentuk ikatan dengannya. Ikatan ini memicu terjadinya perubahan pada domain sitoplasmik dari c-Kit. Perubahan ini memberikan kesempatan pada PLC $\gamma$,
PI3K, dan Shc-Grb2-Sos untuk membentuk komplek dengan c-Kit. Sinyal downstream dari kompleks tersebut memicu degranulasi dengan proses yang mirip dengan sinyal downstream dari ketiganya ketika teraktifkan melalui NTAL dan TAL (Gilfillan \& Rivera, 2009; Lennartsson \& Rönnstrand, 2012).

\section{SIMPULAN, SARAN, DAN REKOMENDASI}

Berbagai jalur sinyal intrasel terjadi ketika sel mast teraktifkan oleh alergen. Ujung perjalanan sinyal intrasel tersebut adalah reorganisasi sitoskeleton yang meliputi pemanjangan mikrotubulus, reorganisasi vimentin, dan degradasi F-aktin sub membran. Reorganisasi ini diikuti dengan degranulasi karena granula terbawa menuju ke arah membran sel dengan proses yang rumit.

Pengetahuan tentang reorganisasi sitoskeleton pada sel mast memberikan harapan baru dalam terapi reaksi hipersensitivitas tipe I dengan cara menghambat reorganisasi sitoskeleton.

Di akhir tulisan ini penulis sangat merekomendasikan untuk melakukan penelitian mengenai uji klinik inhibitor reorganisasi sitoskeleton untuk terapi hipersensitivitas tipe I.

\section{DAFTAR PUSTAKA}

Allen JD, Jaffer ZM, Park SJ, Burgin S, Hofmann C, Sells MA, et al., 2009. p21-activated kinase regulates mast cell degranulation via effects on calcium mobilization and cytoskeletal dynamics. Blood.113:2695-705

Amin K., 2012. The role of mast cells in allergic inflammation. Resp Med,106: 9-14 
Beaven MA., 2009. Our perception of the mast cell from Paul Ehrlich to now. Eur. J. Immunol. 39: 11-25

Blank U, Falcone FH, Nilsson G., 2013. The history of mast cell and basophil research - some lessons learnt from the last century. Allergy. 68:1093101

Bradding P, 2009. Asthma: Eosinophil Disease, Mast Cell Disease, or Both?.Allergy, Asthma Clin Immunol, 4:84-90

Draber P, Halova I, Levi-Schaffer F, Draberov L., 2012. Transmembrane adaptor proteins in the high-affinity $\operatorname{IgE}$ receptor signaling. Front. Immun. 2(95):1-11

Dráber P, Sulimenko V, Dráberová E., 2012. Cytoskeleton in mast cell signaling. Front Immunol, 3(130):1-18

Gadi D, Wagenknecht-Wiesner A, Holowka D, Baird B., 2011. Sequestration of phosphoinositides by mutated MARCKS effector domain inhibits stimulated $\mathrm{Ca} 2+$ mobilization and degranulation in mast cells. Mol Biol Cell, 22(15):4908-17

Gilfillan AM, Rivera J., 2009. The tyrosine kinase network regulating mast cell activation. Immunol Rev. 228(1): 149-69

Ha'jkova' Z, Bugajev V, Dra'berova' E, Vinopal S, Dra'berova' L, Jana'c ček J, et al., 2011. STIM1-Directed Reorganization of Microtubules in Activated Mast Cells. J Immunol, 186:1-12

Huse M., 2009. The T-cell-receptor signaling network. J Cell Sci, 122: 1269-73

Huse M., 2012. Microtubule-organizing center polarity and the immunological synapse: protein kinase $\mathrm{C}$ and beyond. Front Immunol, 3(235):1-11

Kim MS, Radinger M, GilfillanAM., 2008. The multiple roles of Phosphoinositide 3-kinase in mast cell biology. Trends Immunol, 29(10):493-501

Jatmiko SW, Aisyah RA., 2015. Imunitas Alamiah. Edisi 1. Surakarta:UNS Press. 20-2

Lennartsson J, Rönnstrand L., 2012. Stem Cell Factor Receptor/C-Kit: From Basic Science to Clinical Implications. Physiol Rev, 92: 1619 -49

Lessmann E, Leitges M, Huber M., 2006. A redundant role for PKC-e in mast cell signaling and effector function. Int Immunol, 18(5): 767-73

Liu Y, Graham C, Parravicini V, Brown MJ, Rivera J, Shaw S., 2001. Protein kinase $\mathrm{C} u$ is expressed in mast cells and is functionally involved in Fc" receptor I signaling. J. Leukoc. Biol. 69:831-40

Melendez J, Grogg M, Zheng Y., 2011. Signaling Role of Cdc42 in Regulating Mammalian Physiology. J Biol Chem, 286(4):237581

Nayak RC, Chang KH, Vaitinadin NS, Cancelas JA., 2013. Rho GTPases control specific cytoskeletondependent functions of hematopoietic stem cells. Immunol Rev . 256(1):1-23

Nishida K, Yamasaki S, Ito Y, Kabu K, Hattori K, Tezuka T, et al., 2005. FceRImediated mast cell degranulation requires calcium-independent mi crot u bu le-de pendent translocation of granules to the 
plasma membrane. J Cell Biol, 170 (1):115-26

Ogawa K, Tanaka Y, Uruno T, Duan X, Harada Y, Sanematsu S, et al., 2014. DOCK5 Function as a key signalling adaptor that links FceRI signals to microtubule dynamic during mast cell degranulation. J Exp Med, 211(7):1407-19

Okayama Y, Kashiwakura JI, Matsuda A, Sasaki-Sakamoto T, Nunomura S, Yokoi N, et al., 2012. The interaction between Lyn and FceRIb is indispensable for FceRI-mediated human mast cell activation. Allergy, 67: $1241-49$.

Orr SJ, McVicar DW., 2011. LAB/NTAL/ Lat2: a force to be reckoned with in all leukocytes?. J. Leukoc. Biol. 89: 11-19

Polakovicova I, Draberova L, Simicek M, Draber P., 2014. Multiple Regulatory Roles of the Mouse Transmembrane Adaptor Protein NTAL in Gene Transcription and Mast Cell Physiology. PLoS ONE, 9(8): e105539. doi:10.1371/journal. pone.0105539

Pullen NA, Falanga YT, Morales JK, Ryan JJ., 2012. The Fyn-STAT5 pathway: a new Frontier in $\operatorname{IgE}$ and $\operatorname{IgG}$ mediated mast cell signaling. Front Immunol, 3(117): 1-9

Ra C,Nunomura S, Okayama Y., 2012. Fine-tuning of mast cell activation by FceRI $\beta$ chain. Front Immunol, 3(112):1-8

Rivera J, Gilfillan AM., 2006. Molecular regulation of mast cell activation. J Allergy Clin Immunol, 117(6):121425
Schwartz M., 2003. Rho signalling at a glance. J Cell Sci, 117(23):5457-8

Shen WW, Frieden M, Demaurex N., 2011. Remodelling of the reticulum endoplasmic during store-operated calcium entry. Bio Cell, 103:365-80

Sibilano R, Frossi B, Pucillo CE., 2014. Mast cell activation: A complex interplay of positive and negative signaling pathways. Eur. J. Immunol. 44: 2558-66

Siraganian RP., 2003. Mast cell signal transduction from the high-affinity IgE receptor. Current Opinion Immunol, 15:639-46

Siraganian RP, de Castro RO, Barbu MA, Zhang J., 2010. Mast cell signaling: The role of protein tyrosine kinase Syk, its activation and screening methods for new pathway participants. FEBS Letters, 584:4933-40

Theoharides TC, Alysandratos KD, Angelidou A, Delivanis DA, Sismanopoulos N, Zhang B, et al., 2010. Mast cells and inflammation. Biochim Biophysic Acta, 1822:21-33

Tumova' M, Koffer A, Simı'cek M, Dra'berova' L, Draber P., 2010. The transmembrane adaptor protein NTAL signals to mast cell cytoskeleton via the small GTPase Rho. Eur. J. Immunol. 40: 3235-45

Yamasaki S, Ishikawa E, Sakuma M, Kanagawa $\mathrm{O}$, Cheng AM, Malissen B, et al., 2007. LAT and NTAL Mediate Immunoglobulin E-Induced Sustained Extracellular Signal-Regulated Kinase Activation Critical for Mast Cell Survival. Mol Cell Biol, 27(12): 4406-15 